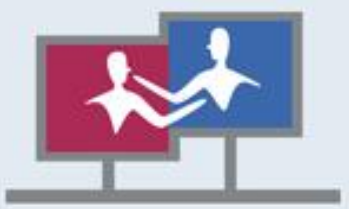

Daneback, K., \& Smahel, D. (2015). Editorial: From single to double digits.. Cyberpsychology: Journal of Psychosocial Research on Cyberspace, 9(4), article 1. doi: 10.5817/CP2015-4-1

\title{
Editorial: From single to double digits
}

\author{
Kristian Daneback ${ }^{1}$, David Smahel ${ }^{2}$ \\ ${ }^{1}$ Department of Social Work, University of Gothenburg, Gothenburg, Sweden \\ ${ }^{2}$ Faculty of Social Studies, Masaryk University, Brno, Czech Republic
}

Dear researchers, colleagues, and readers interested in research on cyberspace,

We are delighted to present the December issue of Cyberpsychology: Journal of Psychosocial Research on Cyberspace (4-2015). While it is the last issue of the year, it is also the last issue in the single digits 2016 marks an anniversary because we are moving into the $10^{\text {th }}$ volume of the journal and 10 years of publishing research on cyberspace! Topics have been diverse throughout the years, although some trends are becoming visible as we are starting to get a substantial archive of published articles. Contrary to this issue - which comprises of four articles from the United States and one from the United Kingdom - we usually have a mix of authors from various parts of the world. Nevertheless, we can see that the number of submissions from the U.S. has increased. Each year we set new records in terms of the number of submitted manuscripts and, while it generates more work for the editorial office, we are grateful that so many researchers consider our journal as an outlet for their work. We are also told by several universities across Europe that the journal is on the list of "accepted" journals for publication.

Next year will see some changes as we are developing new submission system. This will simplify the procedure for both authors and reviewers, but the biggest change will be for the editorial office in terms of managing submissions and reviews. We believe that this will help us deal with the increasing number of submissions - and the work that comes with them - without unnecessary delays. However, technology does not solve all problems. Sometimes finding the right reviewers may take more time than we wish and we do understand this frustration for authors. Fortunately, this is rare and, most of the time, we manage to complete the process within the time we have stated in the journal.

As of this writing, we can also let you know that the first issue of 2016, which is a special issue on selfdisclosure and privacy, is in preparation, and will be published in March. We believe that our habit of publishing two special issues per year has been well received, not the least because it allows us to focus on themes and trends in the field of cyberpsychology. We are now planning the 2017 special issues, and if you are interested in guest editing a special issue or if you would like to propose a specific topic, please let us know.

Now to the current issue, which we hope you will find to be both interesting and a contribution to our field of research.

The first article, "Parental regulation of online behavior: Adolescents' experiences and perspectives" (Goldstein), focuses on how adolescents experience and perceive their parents' regulation and monitoring of their online behavior and activities. Among other things, the results suggest that adolescents were accepting of parental authority and monitoring when it came to cyberaggressive behaviors.

The second article also focuses on young adults and their parents. In "Perceived differences in knowledge about interactive technology between young adults and their parents" (Vaterlaus, Jones, \& Tulane), the authors set out to study generational differences when it comes to interactive technologies. The results show that the perceived knowledge gap between young adults and their parents was increased with newer technologies, for example social networking and video chatting, where the gap was largest. 
The third article, "A review of pornography use research: Methodology and results from four sources" (Gmeiner, Price, \& Worley), compares different sources used for estimating pornography use. They found that three different sources are correlated, but that data from a subscription pornography website differed. They suggest that pornography research relying on paid subscription data may provide misleading conclusions.

The fourth article, "Social networking's peril: Cognitive absorption, social networking usage, and depression" (Brooks \& Longstreet), examines the relationship between usage and depression among social network users. The results indicated that dissociation and heightened enjoyment are associated with increased usage, and that usage is associated with greater levels of depression. In addition, the findings showed differences related to gender.

In the fifth article, "Analysing people with head and neck cancers' use of online support groups" (Algtewi, Owens, \& Baker), online support groups are investigated. For this specific group, online support groups provided information and emotional support that was, to a substantial extent, experience based. The authors suggest their findings are an advantageous source not only for patients, but also for family members and caregivers.

Finally, we would like to thank all of you reviewers and authors who contribute to our journal. We could not do it without you. We also want to thank our readership and worldwide institutional supporters. We wish you a wonderful holiday season and the very best for 2016!

Kristian Daneback, associate editor

David Smahel, editor

\section{Issue Content}

Article 1:

Editorial: From single to double digits

Kristian Daneback and David Smahel

doi: $10.5817 /$ CP2015-4-1

Article 2:

Parental regulation of online behavior and cyber aggression: Adolescents' experiences and perspectives

Sara E. Goldstein

doi: $10.5817 /$ CP2015-4-2

Article 3:

Perceived differences in knowledge about interactive technology between young adults and their parents

J. Mitchell Vaterlaus, Randall M. Jones, and Sarah Tulane

doi: $10.5817 /$ CP2015-4-3

Article 4:

A review of pornography use research: Methodology and results from four sources Michael Gmeiner, Joseph Price, and Michael Worle

doi: $10.5817 /$ CP2015-4-4

Article 5:

Social networking's peril: Cognitive absorption, social networking usage, and depression Stoney Brooks and Phil Longstreet

doi: $10.5817 / C P 2015-4-5$

Article 6:

Analysing people with head and neck cancers' use of online support groups

Eamar E. Algtewi, Janine Owens, and Sarah R. Baker

doi: 10.5817/CP2015-4-6 


\begin{abstract}
About Journal
The 'Cyberpsychology: Journal of Psychosocial Research on Cyberspace' is a web-based, peer-reviewed scholarly journal. The first peer-reviewed issue was published in September 2007. The journal is focused on social science research about cyberspace. It brings psychosocial reflections of the impact of the Internet on people and society. The journal is interdisciplinary, publishing works written by scholars of psychology, media studies, communication science, sociology, political science, nursing, ICT security, organizational psychology and also other disciplines with relevance to psychosocial aspects of cyberspace. The journal accepts original research articles, as well as theoretical studies and research meta-analyses. Proposals for special issues are also welcomed.

The journal is indexed with SCOPUS, ERIH PLUS, EBSCO Academic Search Complete, the Directory of Open Access Journals and the Czech Database of Scientific Journals.

The articles in Cyberpsychology: Journal of Psychosocial Research on Cyberspace are open access articles licensed under the terms of the Creative Commons Attribution Non-Commercial License which permits unrestricted, non-commercial use, distribution and reproduction in any medium, provided the work is properly cited.
\end{abstract}

\title{
Editor
}

Prof. David Smahel, M.Sc. et Ph.D., Faculty of Social Studies, Masaryk University, Czech Republic E-mail: smahel(at)fss.muni.cz

\section{Associate Editor}

Prof. Kristian Daneback, Ph.D., University of Gothenburg, Sweden

E-mail: kristian.daneback(at)socwork.gu.se

\section{Editor Assistant}

Lenka Dedkova, M.A., Faculty of Social Studies, Masaryk University, Czech Republic

E-mail: Idedkova(at)fss.muni.cz

\section{Editorial Board:}

Prof. Kaveri Subrahmanyam, Ph.D., California State University, Los Angeles, USA

Prof. Herbert Hrachovec, Ph.D., University of Vienna, Austria

Prof. Dr. Micheline Frenette, Universite de Montreal, Canada

Prof. Alexander E. Voiskounsky, Ph.D., Lomonosov Moscow State University, Russia

Prof. Michael W. Ross, Ph.D., DrMedSc, MPH, MPHEd, University of Texas, Houston, USA

Prof. Petr Macek, CSc., Masaryk University, Czech Republic

Prof. Olle Findahl, World Internet Institute, Sweden

Prof. Jochen Peter, Ph.D., University of Amsterdam, Netherlands

Prof. Veronika Kalmus, Ph.D., University of Tartu, Estonia

Prof. Joshua Fogel, Ph.D., Brooklyn College of the City University of New York, USA

Prof. Gustavo S. Mesch, Ph.D., University of Haifa, Israel

Michelle Wright, Ph.D., Masaryk University, Czech Republic

Václav Štětka, Ph.D., Charles University, Czech Republic

Andra Siibak, Ph.D., University of Tartu, Estonia

Adjunct Prof. Birgit U. Stetina, Ph.D., University of Vienna, Austria

Lukas Blinka, Ph.D., Masaryk University, Czech Republic

\section{Advisory Board:}

Prof. Bente Traen, Ph.D., University of Oslo, Norway

Prof. Charles Ess, Ph.D., University of Oslo, Norway

Prof. Dr. Ilse Kryspin-Exner, University of Vienna, Austria

Prof. PhDr. Jan Jirák, Ph.D., Charles University, Czech Republic 
Prof. Vasja Vehovar, Ph.D., University of Ljubljana, Slovenia

Prof. Larry D. Rosen, Ph.D., California State University, USA

Prof. Patricia M. Greenfield, Ph.D., University of California, USA

Prof. Peter K Smith, University of London, England

Prof. Nicola Döring, Ilmenau University of Technology, Germany

Prof. Kimberly Young, Ph.D., St. Bonaventure University, USA

Prof. Jos de Haan, Ph.D., Erasmus University, Netherlands

Prof. Zbyněk Vybíral, Ph.D, Masaryk University, Czech Republic

Prof. Monica Whitty, Ph.D., University of Leicester, UK

Prof. Alistair Duff, Ph.D., Edinburgh Napier University, Scotland

Assoc. Prof. Alfred Choi, Ph.D., Nanyang Technological University, Singapore

Prof. Thurasamy Ramayah, Universiti Sains Malaysia, Malaysia

Assoc. Prof. Neil Coulson, Ph.D., The University of Nottingham, UK

Assoc. Prof. Kenneth C. C. Yang, Ph.D., University of Texas at El Paso, USA

Assoc. Prof. Sun Sun Lim, Ph.D., National University of Singapore, Singapore

Prof. Sameer Hinduja, Ph.D., Florida Atlantic University, USA

Assoc. Prof. Jana Horáková, Ph.D., Masaryk University, Czech Republic

Assoc. Prof. Radim Polčák, Ph.D., Masaryk University, Czech Republic

Assoc. Prof. Pille Pruulmann-Vengerfeldt, Ph.D., University of Tartu, Estonia

Assist. Prof. Alexander Schouten, Ph.D., Tilburg University, Netherlands

Assist. Prof. Ewa S. Callahan, Ph.D., Quinnipiac University, USA

Assist. Prof. Regina van den Eijnden, Ph.D., Utrecht University, Netherlands

PhDr. Ing. Petr Soukup, Charles University, Czech Republic

Janis Wolak, Ph.D., University of New Hampshire, USA

Francesca Romana Seganti, Ph.D., Sapienza University of Rome, Italy

Jeff Gavin, Ph.D., University of Bath, UK

Hana Macháčková, Ph.D., Masaryk University, Czech Republic

Michael Fenichel, Ph.D., New York, USA

Leslie Haddon, Ph.D., London School of Economics, UK

Monica Barbovschi, Ph.D., Masaryk University, Czech Republic

Jan Širůček, Ph.D., Masaryk University, Czech Republic

\section{Publisher}

Masaryk University, Faculty of Social Studies

Jostova 10, 60200 Brno

Czech Republic

\section{Publication Schedule}

Four issues per year: two regular issues (in July and December) plus two special issues (between regular issues) 


\section{About authors}

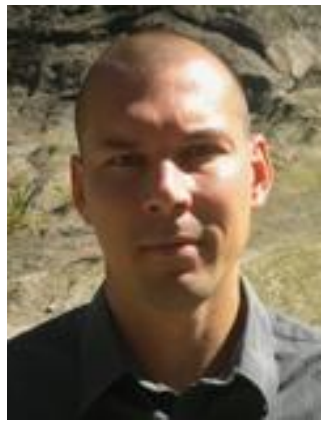

Kristian Daneback, Ph.D. is the Professor of Social Work at the University of Gothenburg, Sweden and in the Faculty of Social Studies at Masaryk University in Brno, Czech Republic. His main field of research is sexuality and in particular internet sexuality, but he is also interested in other internet related phenomena such as parenthood and the internet, cyberbullying, and how the internet can be used to collect qualitative and quantitative data. Daneback has published his research in several well known international journals such as Archives of Sexual Behavior, Cyberpsychology, Behavior, \& Social Networking, Journal of Sexual and Relationship Therapy, Journal of Bisexuality, and Sexual Addiction \& Compulsivity. In addition, he is a reviewer for journals such as Journal of Sex Research, Journal of Computer Mediated Communication, Pediatrics, Sex Roles, and Sexual Reproduction \& Health Care. Currently he serves as the Associated Editor of Cyberpsychology: Journal of Psychosocial Research on Cyberspace and is a Board Member of the Open Journal of Communication and ISRN Family Medicine. Daneback is also a member of the International Academy of Sex Research and the Association of Internet Researchers.

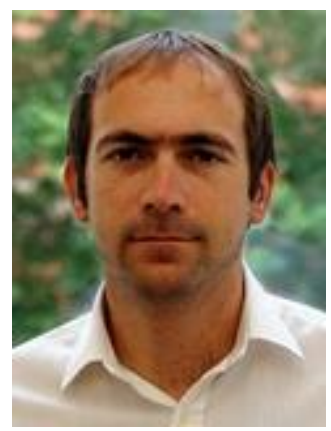

David Smahel, Ph.D. is the Professor at the Institute of Children, Youth and Family Research, Masaryk University, the Czech Republic. He directs the Interdisciplinary Research Team on Internet and Society (IRTIS) which researches social-psychological implications of the internet and technology. Current research focuses on adolescents' and adults' internet use, the online risks of children and adolescents, the construction of online identities and virtual relationships, and online addictive behavior. He is editor of Cyberpsychology: Journal of Psychosocial Research on Cyberspace and has coauthored book Digital Youth: The Role of Media in Development (Springer, 2011). Smahel also published in several international journals such as Developmental Psychology, Cyberpsychology \& Behavior, Zeitschrift für Psychologie, European Journal of Developmental Psychology and others. He is also author of several book chapters, such as in Encyclopedia of Cyber Behavior, Encyclopedia of Adolescence, Internet Addiction: A Handbook and Guide to Evaluation and Treatment, Gesundheit und Neue Medien etc. 